\title{
NUŽNOST UVOĐENJA SADRŽAJA ETIČKOGA OBRAZOVANJA U NASTAVU
}

\section{Dejan Donev}

Institut za filozofiju, Filozofski fakultet, Univerzitet »Sv. Ćiril i Metodij«, Skopje, Sjeverna Makedonija donevdejan@fzf.ukim.edu.mk

Etičko obrazovanje, kao vrsta filozofskog obrazovanja, danas postaje sve aktualnije. Nastava filozofije nije samo razvoj duha nego i put ka samosvijesti i svijesti o ljudskoj dužnosti. Etičke spoznaje i osjećaji osnova su za ljudski, moralni i intelektualni razvoj ličnosti. Mlada ličnost se u susretu s etičkom problematikom i sadržajima uklapa u realnost svijeta kao ljudsko djelo. Kroz etiku ona uspijeva spoznati da je ličnost kontinuitet, ali i progres; da je ličnost dio svoje male zajednice, ali i sastavnica cjeline svijeta. Etičko obrazovanje zanima se za to kako čovjek postaje etička ličnost, jedinka koja slobodno sudi, gradi i razvija moral; što je sadržaj moralne izgradnje ličnosti te koji su stadiji kroz koje ličnost prolazi na tom složenom putu samoizgradnje, od nesvjesnog bića ka biću koje svjesno gradi dobar svijet, ispravne etičke vrijednosti i moralne principe. Dakle, zadatak nije samo stvaranje moralne ličnosti kao jedinke koja »provodi« moral nego je zadatak stvoriti $i$ etički subjekt, tj. ličnost koja slobodno $i$ odgovorno razmišlja i sudi, koja gradi i razvija moral te nove moralne norme. Iz tog je razloga nužno uvođenje kolegija etičkoga obrazovanja u nastavu na sve tri obrazovne razine.

Ključne riječi: etičko obrazovanje, etika, moralni odgoj, filozofija, etički subjekt

\section{Uvod}

Obrazovanje je jedna od temeljnih sastavnica individualnog ljudskog života, kao način na koji život raste i razvija se do ličnosti. Obra- 
zovanje postoji otkada postoji i civilizacija.' Suvremeno čovječanstvo danas više nego ikad ima povećanu potrebu za širokim, kvalitetnim, dugotrajnim i razvijenim obrazovanjem. Iz tog se razloga i kaže da je u mnoštvu brojnih obilježja ove epohe posebno značajna ona prema kojoj je ovo epoha obrazovanja. Izazovi u odgoju postaju jednim od najvećih iskušenja suvremene civilizacije. Svim odgovornim ljudima osnovno je pitanje kako pripremiti buduće generacije za suočavanje s krucijalnim problemima vlastitog opstanka, kao i opstanka generacija koje dolaze, stoga je obrazovanje danas najvažniji zadatak za čovječanstvo i tajna uspješnog svjetskog napretka.

U okvirima obrazovanja posebno je značajno pitanje moralnog odgoja i to ne samo kao pridružene pojave općeg buđenja interesa za etiku nego posebno zbog velike odgojno-aksiološke zapostavljenosti mladih. Problemi izbora vrijednosti, kao i utvrđivanja smisla i spoznavanja kodeksa ljudskog ponašanja, nisu riješeni što za posljedicu ima moralni pad i izgubljenost suvremenog čovjeka u jednom svijetu kojeg on već ne smatra svojim! Nisu više funkcionalne tradicionalne metode i forme izgradnje moralnih stavova. Možemo konstatirati da »suvremeni čovjek boluje od etičke konfuzije « (Legrand, 2001, 10) koja je rezultat opće postmodernističke nesigurnosti, ali i urbanog nasilja, vjerske netolerancije i fanatizma, potrošačkog mentaliteta i brzog tehničkog razvoja današnjice.

Upravo zbog toga se u posljednjim desetljećima inzistira na neophodnosti rehabilitacije odgojne uloge i odgovornosti roditelja i obitelji uopće, a posebno se ističe potreba izlaska iz krize uloge obrazovnih institucija koja je prouzrokovana napuštanjem klasičnih formi jedinstva odgoja i obrazovanja te dominacijom »obrazovnih « nasuprot »odgojnih« ciljeva i djelovanja. ${ }^{3}$ Danas se u školama ponovno posvećuje velika pozornost moralnom odgoju, uvodi se i posebna vrsta etičkog

${ }^{1}$ Još je Kant isticao da je »čovjek jedino biće koje je podložno odgoju«. To je osnovna ideja pedagoške potrebe i djelatnosti (Kant, 1994, 139; 1922, 3).

${ }^{2}$ Za ilustraciju, poznati njemački etičar i teolog Hans Küng ukazuje na probleme u etičkoj svijesti mladih kod kojih se primećuje kriza vrijednosti i dezorijentacija u moralnim normama i djelovanjima (Küng, 1996, 173).

${ }^{3}$ Naime smatralo se da škola i nastavnik ne trebaju imati istaknutu odgojnu ulogu. Radilo se o teorijskom uvidu, ali i o praksi, što se pokazalo kao vrlo negativno po pitanju razumijevanja etike kod mladih generacija. 
obrazovanja, ${ }^{4}$ za što se zalaže i UNESCO predlažući u prvome redu filozofiju (Droit, 1995, 13) kao »školu slobode« (UNESCO, 2007, ix) i način za unaprjeđenje samostalnog mišljenja i prosuđivanja. Na primjer, u Programu UNESCO-a u zadnja tri desetljeća primarna su bila, i još uvijek jesu, četiri etička područja (UNESCO, 1995, 35-36):

1. »Širenje i unaprjeđivanje nastave filozofije na svim razinama obrazovanja kao dijela etičkog obrazovanja, što bi omogućilo razvitak osjećaja za ispravan život $\mathrm{i}$ individualne potencijale za demokraciju;

2. razvijanje svih vrsta istraživanja i prezentacija univerzalne etike, kao neophodne svijesti o jedinstvu svijeta i nužnosti postojanja morala kod svih ljudi;

3. razvoj bioetičkih istraživanja i svijesti, posebno osnivanje bioetičkih udruga u svim društvima i njihovo povezivanje u svjetsku mrežu;

4. osnivanje centara za istraživanje $i$ širenje etike u znanstvenim istraživanjima i njihovo povezivanje širom svijeta.«

$\mathrm{Na}$ temelju navedenoga, osim isticanja moralnoga odgoja, naglasak se sve više stavlja na uvođenje etičkog obrazovanja. Takav poziv predstavlja izraz zabrinutosti za stanje na moralnom planu, koje je teško: lako propuštamo moralne nepodobnosti, svoje moralno-odgojne dužnosti olako odbacujemo (u obitelji, u školi, u državi) te »ne inzistiramo na važnosti morala« (Gill i Thomson, 2020, 44). Drugim riječima, ne širimo znanje o moralu, a lako se oslobađamo od onoga što imamo, pravimo se da moral nije potreban, tvrdimo da se ne zna što je moralno, a što nije itd.

\section{Nužnost etičkog obrazovanja danas}

Sve ove i druge, možda i paradoksalnije etičke situacije, jasno govore o problemima u našem životu i etičkoj orijentaciji. Moramo posjedovati »aksiološke kapacitete za fundamentalnu ljudsku potrebu odmjeravanja svih stvari i pronalaženja pravilnih odgovora na probleme, izazove, dileme« (Franck i Osbeck, 2017, 29). Ljudska bića ne mogu

${ }^{4}$ Preciznije, u članku ćemo koristiti termin 'obrazovanje', a ne 'edukacija' prema odrednici Pastuovića: »U hrvatskom jeziku edukaciji približno odgovara pedagoški pojam 'odgoj' u njegovom ‘širem' značenju, ali bez njegovih vrijednosnih konotacija (...) stoga ćemo naziv edukacija rabiti samo kada mislimo na obrazovanje i odgoj u njihovoj ukupnosti i to onda kada tekst postane prezasićen uzastopnom uporabom složenice 'odgojno-obrazovni', odnosno 'obrazovno-odgojni'...« (Pastuović, 1999, 47) 
živjeti bez odgovornosti. Danas ljudi znaju da je sloboda moguća samo ako imamo razumijevanja za izvršavanje naših dužnosti i obaveza. Ljude vodi razum, oni sagledavaju istinsku vrijednost egzistencije, iz te vrijednosti izvode norme ophođenja i ponašanja te njih provode s uvjerenjem $\mathrm{u}$ ispravnost svoga života.

»Iz etičke slobode i kreativnosti slijedi standardizirani mehanizam moralne obveze, kao uvjerenost $\mathrm{u}$ ispravnost etičke svijesti i neophodnost odgovarajućeg moralnog djelovanja.« (Donev, 2019, 23)

U ovom kontekstu sasvim je opravdano tvrditi da »buđenje etike« (Temkov, 1999, 21) i pojava etičkog obrazovanja u našem vremenu proizlaze iz zbiljskih teškoća u životu prouzrokovanih našom nebrigom u odnošenju s ljudima, iz sagledavanja toga da čovjek može i mora pronaći izlaz iz brojnih teškoća i problema koji pred njim stoje te iz uvjerenosti da je za to neophodna pomoć etike i odgovarajućeg etičkog obrazovanja. Naime, moralno odgajanje sastavni je dio pedagoške teo-

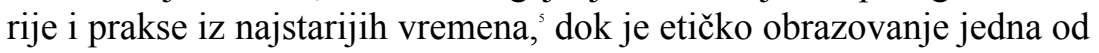
onih vrsta obrazovanja koje su se ponovno probudile s novim pojavama potaknutima socijalnim pokretima, duhovnim izazovima i aktualnim pedagoškim zahtjevima. ${ }^{6}$ Etičko obrazovanje, kao forma etičke i pedagoške djelatnosti, ima za cilj širenje etičkog duha i spoznaje te upravo zbog toga predstavlja bljesak etičke ozbiljnosti i odgovornosti.

Riječ je o obrazovanju u kojemu se ostvaruju vrijednosti za koje čovječanstvo smatra da su najvažnije te da kao takve trebaju biti prenesene na mlade generacije, a preko njih na cjelinu ljudskog postojanja. U tom smislu, sastavni dio obrazovanja je i moralno odgajanje. Međutim, u moralnom odgoju riječ je o postepenoj prilagodbi mlade ličnosti na socijalne ciljeve i vrijednosti te za njeno osposobljavanje za praćenje normi koje uspostavlja društvo. U demokratskom društvu, kakvo uglavnom danas prevladava, od ličnosti se očekuje da ima svoje stavove i da bude graditelj svjetonazora i normi za život. Za ispunjenje toga cilja potrebno je da ona bude obrazovana u duhu spoznaja koje

${ }^{5}$ Moralno odgajanje sastavni je dio općeg odgoja, a teorija moralnog odgoja sastavni je dio pedagogije (Vukasović, 1993, 17).

${ }^{6}$ Zbog ograničenja prostora, ovdje ćemo se samo pozvati na autore koji zagovaraju etičko obrazovanje, tj. izostaviti ćemo one (prije svega iz Hrvatske, npr. Kangrga, Polić i dr.) koji upućuju kritiku takvom pristupu. Te ćemo analize ostaviti za neki budući članak. 
pruža etika te da postane konstruktivan član zajednice kako bi i zajednica mogla ostvarivati pozitivne etičke ciljeve. Odgovornost pada na ličnost pa ličnosti moraju biti pripremljene, i spoznajno i mentalno, za velike izazove koji na polju etike stoje pred njima.

Iz ovoga slijedi da je etičko obrazovanje jedna vrsta vrlo bitne etičkopedagoške aktivnosti današnjice te da ono predstavlja svojevrsno produbljivanje moralnog odgoja. Zapostavljanje moralnog odgoja mladih, kako onoga koji se odvija unutar obitelji tako i onoga u školi, prouzrokovalo je potrebu revitalizacije etičkog obrazovanja kao esencijalnog dijela obrazovanja mladih. Naime, realnost svijeta u ovom kriznom razdoblju probudila je potrebu za moralnim odgajanjem čiji se smisao danas ne ostvaruje samo u transpoziciji postojećih moralnih vrijednosti i razuma mladih generacija nego $\mathrm{i} \gg \mathrm{kroz}$ ostvarenje mladih ljudi kao autonomnih etičkih ličnosti« (Ruggiero, 2012, 3).

Ovo je smisao otkrića švicarskog filozofa i psihologa Jeana Piageta i američkog psihologa Lawrencea Kohlberga koji su u okvirima istraživanja moralnog duha ličnosti i njena razvoja utvrdili stupnjeve etičkoga razvoja od heteronomne ka autonomnoj ličnosti. Uslijedilo je osmišljavanje etičkog obrazovanja u vidu posebnog predmeta kojim se potiče etički razvoj mlade ličnosti do stupnja njene vrijednosne samostalnosti i etičke kreativnosti.

Dakle, »nije dovoljno imati ličnost koja će pratiti normativni sustav, koji ionako nije dobar i ne odgovara zahtjevima epohe, u ovom izvrnutom i zbunjenom suvremenom svijetu« (Peševska-Zarevska, 2003, 39). Čovječanstvu su potrebne ličnosti koje znaju razmišljati o složenim problemima današnjice i budućnosti, kod kojih je razvijeno vrijednosno razmišljanje i pozitivno odlučivanje, ličnosti koje znaju pronaći pravo rješenje i koje su spremne boriti se za njega. Mi živimo u vremenu individualnih sloboda i odgovornosti, a etika treba svakome omogućiti znanje, želju i snagu da postupi pravilno. To je neophodno da bismo mogli opstati: »Etika je jedino sredstvo pomoću kojeg ćemo osigurati budućnost« (Major i Tangijan, 1997, 5). 


\section{Etičko obrazovanje, ali ne kao sinonim za moralno odgajanje}

Suvremeno etičko obrazovanje ima sličnu dimenziju i zadatak kao i moralno odgajanje, ali i od njega drugačije dimenzije i zadatke. I etičko se obrazovanje bavi procesom moralne izgradnje ličnosti, ali njegova ideja, ciljevi i zadaci usmjereni su prije svega na to da od mladog obrazovanog subjekta stvore slobodnu i odgovornu ličnost, s vlastitim etičkim kapacitetom i stvaralačkim etičkim habitusom. Cilj nije izgradnja ličnosti prilagođene na konkretni moral, već ličnost koja zna ocjenjivati i kreirati vrijednosti, odnosno koja samostalno moralno prosuđuje i stvara moral. Takvo etičko obrazovanje zapravo predstavlja

»... dijalektičku nadgradnju i nadogradnju klasičnog moralnog odgoja: moralno odgajanje je sačuvano u okvirima etičkog obrazovanja, ali njegovi zadaci nisu primarni, oni se 'nadilaze' u širem i ozbiljnijem zadatku nove vrste etičkog obrazovanja.« (Sprod, 2001, 3)

Dakle, zadatak nije samo stvaranje moralne ličnosti jedinke koja "provodi« moral nego je zadatak stvoriti i etički subjekt, tj. ličnost koja slobodno i odgovorno razmišlja i sudi te koja gradi i razvija moral i nove moralne norme.

Ovo je izraz jedne šire antropološke i socijalne vizije, i jednog osobenog pedagoškog zadatka. Pritom, posebno su razvijeni problemi sadržaja moralne izgradnje ličnosti i pedagoške forme za taj cilj. Osnova za to postavljena je u spoznaji o stadijima kroz koje ličnost prolazi na putu samoizgradnje. U takvom se ostvarivanju od nesvjesnog bića izgrađuje biće koje je sposobno za promišljanje, izbor i izgradnju jednog dobrog, tj. boljeg svijeta, odnosno za pravilno ocjenjivanje te za osobno i kreativno zastupanje etičkih vrijednosti i moralnih principa. U ovakvom pristupu etičko obrazovanje pretvara se u proces individualnog moralnog razvitka. Riječ je o procesu u kojemu se mlada ličnost od nezrele, nesvjesne i neautonomne postepeno izgrađuje u zrelu, svjesnu i autonomnu ličnost.

Ovakvoj inovaciji i revoluciji etičkog obrazovanja doprinijela su ispitivanja Jeana Piageta i Lawrencea Kohlberga. Naime, do današnje epohe izučavanje etike, osim u znanstvene svrhe, uglavnom je imalo značaj za moralno odgajanje $\mathrm{i} »$ instruiranje « u profesionalnoj etici. Nakon istraživanja Piageta i Kohlberga etičko obrazovanje postaje sastav- 
nim dijelom nomenklature najznačajnijih obrazovnih područja. Poslije ovih značajnih psihologa i filozofa obrazovanja, ova nastavna aktivnost počela se nazivati etičkim obrazovanjem. Naime, cilj moralnog odgoja je specifična izgradnja ličnosti.

»Moralno odgajanje označava proces moralnog oblikovanja ličnosti, proces formiranja jedinke u društvenu ličnost, usuglašen s prihvaćenim moralnoetičkim stavovima.« (Vukasović, 1974, 19)

\section{Pod ovim se podrazumijeva}

»... proces oblikovanja moralnih kvaliteta čovjeka, oblikovanje njegove moralne svijesti, pogleda i stavova, razvijanje moralnih osjećaja, pozitivnih svojstava volje i karaktera, oblikovanje vještina i navika moralnog ponašanja i postupanja u određenom društvu u suglasnosti s prihvaćenim moralno-etičkim shvaćanjima. Moralno odgajanje je organizirana, svjesna, namjerna, svrsishodna, intencionalna djelatnost određene zajednice s ciljem prihvaćanja i ostvarivanja temeljnih etičkih načela i postavki te zajednice.« (Vukasović, 1974, 84)

U tom smislu, komponente etičkog obrazovanja odnose se na njihove različite zadatke: moral regulira odnose među ljudima, etika proučava moral i unaprjeđuje ga, a moralno odgajanje ga podržava i realizira.

Dakle, bit moralnog odgoja je u socijalizaciji ličnosti, u pripremi da ona prihvati i nauči moralne principe i svoju moralnu svijest koristi za prilagodbu u konkretnu sredinu i za što adekvatniji »smještaj« u sustav odnosa u društvu.

»Sadržaj i, prema tome, cilj moralnog odgoja, određuju moralne norme koje vladaju ili koje tek nastaju u društvu.« (Krneta i Potkonjak, 1969, 375)

Etičko obrazovanje gradi se na osnovi sagledavanja procesa moralne izgradnje ličnosti, ali je njegova ideja prije svega usmjerena ka suštinskoj i autentičnoj samoizgradnji svih etičkih dimenzija ličnosti. Etičko obrazovanje zanima se za to kako čovjek postaje etičkom ličnošću, jedinkom koja slobodno sudi, gradi i razvija moral; što je sadržaj moralne izgradnje ličnosti te koji su stadiji kroz koje ličnost prolazi na tom složenom putu sebeizgradnje od nesvjesnog bića ka biću koje svjesno gradi dobar svijet, pravilne etičke vrijednosti i moralne principe. U ovom kontekstu etičko obrazovanje dopunjuje moralno odgajanje koje predstavlja osposobljavanje mlade ličnosti u društvenim normama i tendencijama, njenu postepenu prilagodbu na socijalne ciljeve i vri- 
jednosti te njeno osposobljavanje za praćenje i izvršavanje društvenih normi. Za razliku od moralnog odgoja koje se nameće moralnoj spoznaji i upućuje na volju za ostvarenje već određenih ciljeva i smjerova, u etičkom obrazovanju radi se o »izgradnji kapaciteta za slobodno razmišljanje, etičku 'skepsu' i djelovanje« (Todd, 2003, 5).

Sumirano, etičko obrazovanje je odgojno-obrazovna forma kroz koju se ličnost mladog čovjeka izgrađuje u slobodan, zreli i odgovoran moralni subjekt. Ovo se

»... treba primjenjivati još u najranijoj dobi, u prvim susretima sa školskim sustavom, i s njime nastaviti tijekom cijeloga obrazovanja kako bi rezultati omogućili neophodnu ljudsku rezervu svijesti i slobodne volje odgovorne ličnosti, a koji su neophodni za unaprjeđenje života i rješavanje ozbiljnih pitanja.« (Crisp i Slote, 1997, 26)

Ovo je posebno važno zato što kognitivni i materijalni razvoj suvremenog svijeta treba biti praćen, prožet i usuglašen s etičkim razvojem. Etički razvoj nije tek puki dodatak kognitivnom i moralnom razvoju, već je ravnopravan aspekt njihova plodonosnog razvoja.

\section{Svrha nastave etičkog obrazovanja}

Moralni odgoj jedna je od esencijalnih dimenzija obrazovanja, a pedagogija je, u svojoj suštini, primijenjena etika. U suvremeno doba, a nakon značajnih istraživanja psihologa, pedagoga i etičara, sve se više ukazuje na specifičnosti etičkog obrazovanja. Ono dobiva svoju autentičnost, odnosno ne tretira se samo kao primijenjeni društveni moral ili kao produženo moralno odgajanje, što možemo zahvaliti istraživanjima Jeana Piageta i Lawrencea Kohlberga. Od mnogobrojnih Piagetovih istraživanja, posebno onih koja su se usmjerila na sagledavanje nastajanja dječje svijesti i razvoja ponašanja, za etiku je posebno važno ono provedeno 1932. godine, a koje je bilo usredotočeno na izgradnju moralnog suda kod djeteta (Piaget, 1978). Kako navodi Mirić, »radi se o prvom sustavnom pothvatu na polju moralnog mišljenja« (Mirić, 2001, 97). Piaget je utvrdio da se moralna svijest razvija ne samo ka većem prihvaćanju i razumijevanju moralnih stavova, nego i ka izgradnji etičkog kapaciteta ličnosti koja postaje moralnim subjektom, sudi samostalno i ima svoje moralne stavove. 
Realno je da mala djeca nemaju vlastite moralne stavove jer se »dijete orijentira prema autoritetu, a time počinju i njegova socijalizacija, odgajanje i moralni razvoj» (Težak i Čudina, 1996, 17). Drugim riječima, djeca su etički heteronomna, ona izvršavaju naloge koje im daju stariji, odnosno oni koji imaju nadređenu etičku funkciju u njihovoj zajednici. Vuko Pavičević ukazuje na dva aspekta ove heteronomne faze u razvitku moralne svijesti i ličnosti uopće: to je faza »u kojoj još ne postoji pravo razumijevanje značaja i smisla onih zahtjeva koji se postavljaju pred djecu i koje ona trebaju ispuniti« te u kojoj se, pomoću raznih mjera, »moraju mobilizirati motivi zadovoljstva i nezadovoljstva kao psihološka podloga za usvajanje normi« (Pavičević, 1974, 61). Druga faza je faza moralne autonomije u kojoj ličnost izražava seberazumijevanje kao moralnog subjekta i svjesno se usmjerava ka moralnom djelovanju kao izrazu provođenja vlastitih etičkih vrijednosti i principa. Kako navodi Piaget: »moral se razumije kao slobodno djelovanje« (Piaget, 1997, 110-112). Pri ocjenjivanju moralne ličnosti i postupka dominira smisao i značaj namjere, a odgovornost je izraz subjektivnog shvaćanja te nema potrebe za nagrađivanjem ili kažnjavanjem kao poticajima za moralno djelovanje. Heteronomija i autonomija osnovne su kategorije za razlikovanje ovih bitnih razvojnih i etičkih faza ličnosti: »za manju djecu pravila su svetinje i ona imaju svojstvo tradicije, a za veću djecu pravila ovise o dogovoru. Heteronomija i autonomija dva su pola ove evolucije« (Piaget, 1997, 84-100).

Što se tiče Lawrencea Kohlberga, jednog od najpoznatijih suvremenih psihologa morala, on je pružio vrlo značajnu teoriju o stupnjevima moralnog razvoja čime je proširio, detaljizirao i dodatno objasnio osnovne pozicije Piageta. U svojoj knjizi Psihologija moralnoga razvoja (Kohlberg, 1981) on ukazuje na etički razvoj kao proces koji ličnost vodi od normi nekog autoriteta ka normama imanentnih samom djelovanju i spoznavanju ličnosti (npr., onih o uzajamnosti i simpatijama). Kohlberg ustanovljava šest stupnja u razvoju moralnog suđenja, koji se iskazuju kroz tri razine moralne svijesti; svaka razina ima po dva stupnja. ${ }^{8}$ Iz svega ovoga proizlaze vrlo značajni Kohlbergovi zaključci

\footnotetext{
${ }^{7}$ Detaljnije vidjeti u: Singer, 1991, 464-475.

${ }^{8}$ Za razvojne stadije kod Kohlberga detaljnije vidjeti u: Kapor-Stanulović, 1988, 95101.
} 
o dominantnim motivima u razvoju ličnosti, a koje on sumira $u$ šest moralno-socijalnih stadija: u prvom stupnju osoba se trudi biti poslušna i izbjeći kaznu; u drugom stupnju ona se trudi zaslužiti nagradu i zaštititi vlastiti interes, a »polako otkriva značaj odnosa s drugim ljudima« (Kohlberg, 1976, 33); u trećem stupnju pojedinac nastoji ostvariti suglasnost s drugima i izbjeći tuđe negodovanje i neodobravanje zbog njegovoga ponašanja; $u$ četvrtom stupnju motiv ličnosti je orijentiran ka zakonu i poretku, što znači da se ona trudi izbjeći neodobravanje od strane legitimnih autoriteta, kao i osjećaj krivnje koji bi iz toga proizišao; u petom stupnju motiv ličnosti je socijalni dogovor, odnosno želja da osvoji odobravanje nepristranih prijatelja koji nastoje osigurati blagostanje društva; u šestom stupnju, s orijentacijom ka univerzalnim etičkim principima i kroz intimni odnos s moralom kod ličnosti se formira visok osjećaj samodostojanstva (Sotirova, 1995, 76-78). Intelektualni razvoj ličnosti istovremeno vodi ka razvitku njenih socijalnih spoznaja, emocija i ponašanja koji traju do druge razine socijalno-moralnog ponašanja, a u posljednjoj fazi razotkrivaju visoku etičku dimenziju zrele ljudske ličnosti. Stvaranje takve ličnosti zadatak je današnjeg obrazovanja, posebno etičkog obrazovanja kao specifične vrste personalnog obrazovanja. Posredstvom etičkog obrazovanja dolazi se do »novih antropoloških i psiholoških spoznaja o strukturi ličnosti i njenom razvoju od heteronomnog ka autonomnom biću koje samo donosi svoje etičke vrijednosti i moralne norme« (Gill i Thomson, 2020, 53).

Filozofi, psiholozi i pedagozi tako su pronašli novi način izgradnje ličnosti. Nove znanstvene spoznaje ispituju suštinu etičkog razvoja ličnosti od najmlađih godina do zrelosti. Nije dovoljno ličnost oblikovati spram realnih ili zamišljenih moralnih vrijednosti. Nju treba osposobiti za osmišljavanje života, razotkrivanje pravih problema i njihovo rješavanje na način koji vodi progresu. To je suština etičkog obrazovanja kao novog sadržaja u podizanju mladih generacija, a preko koje se opravdava i dokazuje potreba postojanja novog pedagoškog područja kojeg nazivamo etičkim obrazovanjem.

Radi se o novoj nastavnoj materiji i kurikulumu pomoću kojih se u ukupni odgojno-obrazovni proces unose sadržaj i metode autonomnog etičkog mišljenja te proširuje i učvršćuje neophodni stupanj moralnog odgoja mladih generacija. Ovo se odnosi i na šire okvire ljudskoga osmišljavanja života i svijeta, kao prve osnove i uvjeta njegova uku- 
pnog opstanka i djelovanja te kao baza njegova vrednovanja i postupanja. Stoga i etička »doktrina« mora sadržavati etičke orijentacije i vrijednosti suvremenog društva. Slijede spoznavanje, etički zahtjevi i norme sadašnje i buduće visoko razvijene ljudske civilizacije, kao i sustav moralnih i pravnih normi modernog društva, s obzirom na njegove planove i priželjkivane životne ciljeve, odnose među ljudima i vizije o izgradnji ljudskih resursa, ljudske ličnosti, njenog djelovanja te odnosa s drugima u društvu.'

Cilj etičkog obrazovanja u osnovnim školama je potaknuti osobno i moralno osvještavanje mladih ličnosti, kao i njihovu samospoznaju u mreži socijalnih odnosa u kojima se nalaze, zatim upoznavanje s osnovnim moralnim normama u najvažnijim područjima njihova svakodnevnog života (emocionalnim odnosima, zdravlju i drugim socijalnim relacijama). Na srednjem stupnju obrazovanja glavna je namjera upoznavanje mladih s aspektima etike, mehanizmom etičkog odlučivanja, značajnim svjetskim rješenjima etičkih dilema, kao i s vrijednostima i normama u nekim važnim područjima života (zdravlje, obitelj, rad, politika itd.). Što se tiče razine studija, studenti bi trebali »izučavati najznačajnije ideje moralnog života i djelovanja, upoznati se s pogledima najpoznatijih etičkih mislitelja i s osnovama profesionalnog morala« (Lozanovski, 1999, 14-15).

»Ljudima su potrebni novi sadržaji, novi izazovi, novi ciljevi, a sve je to usmjereno ka postizanju najviše vrline: da se bude i da se ostane Čovjek.« (Pismo grupe studenata filozofije na Filozofskom fakultetu u Skopju, 1998, 7)

Etičko obrazovanje pretpostavka je za razvijeni etički život budućih odraslih i zrelih pojedinaca, u jednoj zdravoj etičkoj sredini i u sustavu vrijednosti jednog zrelog društva.

»Bez etičkog obrazovanja generacije djece i mladih unaprijed su osuđene na potpuno dezorijentaciju, a koja je u razdoblju tranzicije poremetila tradicionalne vrijednosti njihovih roditelja. Neodgovorni odnos prema sebi i prema svijetu samo je posljedica nesređenosti i kaotične moralne situacije naše sadašnjosti. Etičko obrazovanje i etika trebaju početi u obrazovanju (...) dok ne postanu sastavnim dijelom kulture života u kojoj će dobro biti imperativ i smisao postojanja.« (Frangovska, 1998, 54-55)

\footnotetext{
${ }^{9}$ Vidjeti poglavlje IV »Resolving Ethical Dilemmas in Different Situations« u Scott, 1998.
} 


\section{Zaključak}

Etičko obrazovanje je danas postalo posebnom vrstom filozofskog obrazovanja mladih generacija. Nastava filozofije nije samo razvoj duha nego i put ka samosvjesnosti i svijesti o ljudskoj dužnosti. Etičke spoznaje i osjećaji osnova su za ljudski, moralni i intelektualni razvoj ličnosti. UNESCO inzistira na razvijenom redovnom filozofskom i etičkom obrazovanju mladih na svim razinama obrazovanja, još od 2004. godine kada su inicirali Ethics Education Programme (EEP) (UNESCO, 2021). Mlada ličnost se u susretu s etičkom problematikom i sadržajima uklapa u realnost svijeta kao ljudsko djelo. Kroz etiku ona uspijeva spoznati da je ličnost kontinuitet, ali i progres; »da je ličnost dio svoje male zajednice, ali i sastavni dio cjeline svijeta; da je ona graditelj svoga doma i obitelji, ali i zajednički graditelj (sa svim ljudima) cijelog čovječanstva« (Todd, 2003, 1).

$\mathrm{Na}$ osnovu ovih pozitivnih ideala sa svojim inzistiranjem na vrlini, dobrobiti, altruizmu, pozitivnom egoizmu, suradnji, solidarnosti, ukupnim rješenjima koje nudi za probleme ugrožavanja opstanka čovjeka i novim usponom humanizma, etičko obrazovanje postaje vodećom duhovnom disciplinom i neophodni dijelom obrazovanja. Ovakvo etičko obrazovanje predlaže i UNESCO ${ }^{10}$ na svim razinama obrazovanja mladih kako bi ih se pripremilo za velike izazove pred kojima stoji čovječanstvo 21. stoljeća." Etičko obrazovanje nezamjenjiv je dio ukupnoga obrazovanja na svjetskoj razini. Tako usmjerena nastava mladim bi ljudima pomogla razumjeti realnost i značaj problema morala u društvu. Nastava etičkog obrazovanja usmjerila bi se na to da mladi uoče pozitivna idejna rješenja vrijednosti života, da se upoznaju s aksiologijom suvremenog čovječanstva i našeg društva; $s$ hijerarhijom vrijednosti, $t j$. »sa spoznajom da konkretne norme za moralno postupanje i ponašanje proizlaze iz apstraktnijih, trajnijih i viših životnih interesa, vrijednosti i ciljeva« (Gill i Thomson, 2020, 46).

Etičko obrazovanje kod mladih ljudi gradi povjerenje u zadane dužnosti i odgovornosti, kao i svijest o neophodnosti njihova izvršavanja; ono ih upoznaje s posebnostima odgovornosti i normi u raznim

\footnotetext{
${ }^{10}$ Detaljnije vidjeti u: ten Have, 2012.

${ }^{11}$ Uputno je pogledati: Facer, 2021.
} 
sferama moralnog ljudskog života (obiteljskoj, privatnoj, javnoj, profesionalnoj, socijalnoj, političkoj); podučava ih značaju i važnosti bioetike, zdravstvene etike i aspekata očuvanja zdravlja i života ljudi i drugih bioloških vrsta bez kojih ni ljudska vrsta ne može opstati; podučava ih o tome kako da izbjegavaju ovisnosti i da se čuvaju opasnih zaraznih bolesti. Ovakva nastava naše potomke može potaknuti na dolaženje do novih spoznaja ekološke etike i, što je možda najvažnije, usmjeriti ih ka uzimanju u obzir vlastitih interesa, ali i njihova usuglašavanja s općim interesima.

»Razvijajući kritičku i samokritičku svijest za detektiranje i razlikovanje lažnih od istinitih interesa i vrijednosti, etičko obrazovanje bi se trudilo da od mladih naraštaja muškaraca i žena stvori moderne i slobodne ličnosti, ali i dobre ljude, te da pritom postanu i ostanu pravi prijatelji sebe samih i drugih«. (Peševska-Zarevska, 2003, 38)

\section{Literatura}

Crisp, Roger i Slote, Michael (1997), Virtue Ethics, New York: Oxford University Press.

Donev, Dejan (2019), Priračnik za etika, Skopje: UKIM.

Droit, Roger-Pol (1995), Philosophy and Democracy in the World, Paris: UNESCO Publ.

Facer, Keri (2021), Futures in Education: Towards an Ethical Practice, Bristol: University of Bristol.

Franck, Olof i Osbeck, Christina (2017), Ethical Literacies and Education for Sustainable Development, Cham: Palgrave Macmillan.

Frangovska, Jasna (1998), »Imperativ na opstojuvanjeto«, Makedonija Denes, 19 noemvri 1998., str. 54-55.

Gill, Scherto i Thomson, Garett (2020), Ethical Education: Towards an Ecology of Human Development, Cambridge: Cambridge University Press.

Have, ten Henk (2012), Ethics Education: A Challenge for International Cooperation. Dostupno na: http://www.unesco.org/new/en/social-and-human-sciences/themes/bioethics/sv0/news/ethics_education_a_challenge_for_internati-

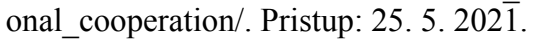

Kangrga, Milan (1989), Etika ili revolucija, Zagreb: Naprijed.

Kant, Immanuel (1994), Sportot na fakultetite - Pedagogika, Sofija: Hristo Botev.

Kant, Immanuel (1922), Spis o pedagogiji, Beograd: Štamparija Davidović Pavlović i drugi. 
Kapor-Stanulović, Nila (1988), Na putu ka odraslosti, Beograd: Zavod za udžbenike i nastavna sredstva.

Kohlberg, Lawrence (1976), »Moral stages and moralization: The cognitive-development approach«, u: Lickona, Thomas (ur.), Moral Development and Behavior: Theory, Research and Social Issues, New York: Holt, Rinehart and Winston, str. 31-53.

Kohlberg, Lawrence (1981), The Philosophy of Moral Development. Moral Stages and the Idea of Justice, San Francisco: Harper \& Row.

Krneta, Ljubomir i Potkonjak, Nikola i dr. (1969), Pedagogija, II tom, Zagreb: Matica hrvatska.

Küng, Hans (1996), »Global ethics and education in tolerance«, Diogenes, 176 (44/176), str. 137-155.

Legrand, Louis (2001), Moralna izobrazba danas, Zagreb: Educa.

Lozanovski, Jovan (1999), Etičkoto obrazovanie vo srednite učilišta vo Republika Makedonija, Skopje: Filozofski fakultet - Institut za filozofija, magisterski trud.

Major, Federik i Tangijan, Sema (1997), UNESCO: Ideal i akcija i aktuelnost jednog vizionarskog teksta: Federiko Major u saradnji sa Semom Tangijanom, Beograd: Zavod za udžbenike.

Mirić, Jovan (2001), Razvoj moralnog mišljenja, Beograd: Kalekom.

Pastuović, Nikola (1999), Edukologija: Integrativna znanost o sustavu cjeloživotnog obrazovanja i odgoja, Zagreb: Znamen.

Pavičević, Vuko (1974), Osnovi etike, drugo prošireno izdanje, Beograd: BIGZ.

Peševska-Zarevska, Olga (2003), »Mladite i etičkoto obrazovanie«, Start, 220, str. $35-40$.

Piaget, Jean (1978), Le jugement moral chez l'enfant, Paris: Presses universitaires de France.

Piaget, Jean (1997), The Moral Judgment of the Child, New York: Free Press.

Pismo od grupa studenti na filozofija na Filozofskiot fakultet vo Skopje (1998), »Etikata e suštinska«, Forum, 7(27), str. 7.

Polić, Milan (2006), Činjenice $i$ vrijednosti, Zagreb: Hrvatsko filozofsko društvo.

Ruggiero, Vincent (2012), Thinking Critically about Ethical Issues, New York: McGraw-Hill Education.

Scott, Graham (1998), Making Ethical Choices - Resolving Ethical Dilemmas, Minnesota: Paragon House.

Singer, Peter (1991), »Morality and psychological development«, u: Singer, Peter (ur.), A Companion to Ethics, Oxford: Blackwell Publishers Ltd., str. 464475.

Sotirova, Daniela (1995), Biznes-etika, Sofija: Industri Ideja. 
Sprod, Tim (2001), Philosophical Discussion in Moral Education, London: Routledge.

Temkov, Kiril (1999), Etikata denes, Skopje: Epoha.

Težak, Dubravka i Čudina-Obradović, Mira (1996), Priče o dobru, priče o zlu, Zagreb: Školska knjiga.

Todd, Sharon (2003), Learning from the Other, Albany: State University of New York.

UNESCO (1995), Major Programme II: The Science in the Service of Development, Programme II.3: Philosophy and Ethics, Paris: UNESCO Publ.

UNESCO (1996), »Pariska deklaracija za filozofijata«, Filozofska tribina, 12, Skopje, str. 144.

UNESCO (2007), Philosophy: A School Of Freedom, Paris: United Nations Educational, Scientific and Cultural Organization Social and Human Sciences Sector.

UNESCO (2021), Philosophy at UNESCO: Past and Present. Dostupno na: https://wayback.archive-it.org/10611/20171122142550/http://www.unesco. org/new/en/social-and-human-sciences/themes/most-programme/humanities-and-philosophy/philosophy-at-unesco-past-and-present/. Pristup: 25.5. 2021.

Vukasović, Ante (1974), Moralni odgoj, Zagreb: Liber.

Vukasović, Ante (1993), Etika, moral, osobnost, Zagreb: Školska knjiga. 


\title{
THE IMPORTANCE OF INTRODUCING ETHICS EDUCATION IN THE CURRICULA
}

\author{
Dejan Donev
}

Nowadays, the ethics education, as a type of philosophical education, is becoming increasingly important. Philosophical education concerns itself with the development of spirit, and with both the development of self-awareness and the awareness of our duties. Ethical insights and feelings are basis for human moral and intellectual growth. Young person becomes a part of the reality of the world through her encounter with ethical issues and contents. Ethics helps in gaining knowledge on the continuity of the concept of person, as well as awareness of its progressive nature. Ethics also aids in realization that person is a part of a particular community but that s/he also participates in human community in general. Ethics education is interested in questions like: how a man becomes an ethical personality, an individual with the freedom of thinking, judging, and acting morally; what is the content of the moral development and what are the stages of that complex process of self-growth from the unreflected being towards the being who consciously deals with ethics values and moral principles. The aim of ethics education is not only the creation of a moral person who merely acts on moral principles, but who is also an ethical subject, i.e. who thinks and acts freely and responsibly, builds and develops moral and creates new moral norms. Thus it is necessary to introduce ethics education in the curricula on all levels of education.

Keywords: ethics education, ethics, moral education, philosophy, ethical subject 